\title{
Oral Health and Diet in Populations of Central Argentina during the Late Holocene: Bioarchaeological and Isotopic Evidence
}

\author{
Mariana Fabra (1D y Claudina V. González
}

\begin{abstract}
We studied the temporal and spatial variation of diet and oral health of human populations that inhabited the central region of Argentina during the Late Holocene (4000-300 BP) by evaluating isotopic data $\left(\delta^{13} \mathrm{Ccol}, \delta^{15} \mathrm{~N}\right)$, physiological stress indicators (tooth wear), and infectious dental diseases (caries). The sample of 49 individuals was recovered from archaeological sites located in the province of Córdoba, dated by AMS on collagen to a range of $4058 \pm 89$ years BP to $370 \pm 15^{14} \mathrm{C}$ years BP. After calculating the prevalence of caries and the average dental wear, we compared these values based on regional origin (central highlands and eastern lowlands), temporal assignation (early Late Holocene, late Late Holocene), and sex (female and male). We found clear regional and temporal differentiation, which we interpret as resulting from differential use of plant resources among the regions and a slight deterioration in oral health in the Late Holocene. Stable isotope analysis indicates food consumption of $C_{3}$ and $C_{4}$ resources, although the observed temporal variations in the isotopic values may indicate an introduction of $\mathrm{C}_{4}$ resources in the later Late Holocene, mainly in the mountainous region.
\end{abstract}

Keywords: $\delta^{13} \mathrm{C}_{\mathrm{col}}$ and $\delta^{15} \mathrm{~N}$ ratios, dental caries, tooth wear, Córdoba, Argentina

El objetivo de este trabajo es estudiar la variación espacial y temporal de la dieta y la salud oral de las poblaciones humanas que habitaron el centro de Argentina en el Holoceno tardio (4000-300 años aP), a través del análisis de datos isotópicos $\left(\delta^{13} C_{c o l}, \delta^{15} N\right)$, marcadores de estrés fisiológico (desgaste dental) y enfermedades de origen infeccioso (caries). La muestra corresponde a un total de 49 individuos, cada uno con información radiocarbónica por AMS, recuperados en sitios arqueológicos de la provincia de Córdoba. Se calcularon prevalencias de caries y promedios de desgaste dental y se realizaron comparaciones considerando la región, la cronología y el sexo de los individuos. Se aplicó el test de Mann-Whitney U para evaluar la significancia estadística de las diferencias observadas. Los resultados de las patologías orales, así como los datos isotópicos sugieren una clara diferenciación regional y temporal. Esto puede interpretarse como resultado del uso diferencial de vegetales entre las distintas regiones, así como un desmejoramiento en la salud hacia finales del Holoceno tardío. Los análisis isotópicos sugieren el consumo de vegetales con vías fotosintéticas $C_{3}$ y $C_{4}$, con una introducción tardía de estos últimos, principalmente en la región serrana.

Palabras clave: $\delta^{13} \mathrm{C}_{\mathrm{col}}$ y $\delta^{15} \mathrm{~N}$, caries dentales, desgaste dental, Córdoba, Argentina

$\mathrm{T}$ eeth are particularly resistant to deterioration and postdepositional degradation; hence they are better preserved than bones and, in many cases, are the only source of information remaining intact that we have about past human populations (Huss-Ashmore et al. 1982). Studying the diet of a human group through their dentition allows us to infer the type of food that is usually consumed, techniques of preparation, and paramasticatory activities (Scott and Turner 1988).

In recent years, a number of studies have been conducted on the diet and oral health of ancient populations of southern South America (e.g., Barrientos 1999; Bernal et al. 2007; Bonomo et al. 2017; Flensborg et al. 2018; Gil et al. 2017; L'Heureax 2000; Novellino 2002; Novellino and Gil 2007; Novellino et al. 2004;

Mariana Fabra and Claudina V. González a Instituto de Antropología de Córdoba (Consejo Nacional de Investigaciones Científicas y Técnicas) and Museo de Antropología (Facultad de Filosofía y Humanidades, Universidad Nacional de Córdoba), Av. Hipólito Yrigoyen 174, CP. 5000, Córdoba, Argentina (marianafabra@ gmail.com, corresponding author) 
Ottalagano and Loponte 2016; Tessone et al. 2009). Despite this focused attention, the lifestyle of the populations of central Argentina has not been systematically addressed. Some limited exploration of dental wear or dental hypoplasia can be found in research articles or archaeological reports (Fabra 1999), but it was not until recently that this analysis has been conducted at a regional scale (Fabra and González 2015; Fabra et al. 2012, 2014; González 2016; González and Fabra 2018; Laguens et al. 2009).

The last few decades of archaeological research in the central region of Argentinamore precisely, the area occupied by the central hills and pampas to the east within the province of Córdoba-have indicated that the region was occupied 10,000 years ago. Its inhabitants developed diverse and successful adaptations to the environment (Laguens 1999; Laguens and Bonnin 2009). Throughout the Holocene, they developed effective technologies and modes of exploitation of resources, maintaining hunting and gathering subsistence strategies for several millennia. At around 2000-1500 BP, new technologies and processes, including ceramic production, a sedentary lifestyle, and the incorporation of horticultural practices, complemented previous hunting and gathering strategies. These processes represented a new way of life that was distinct from those developing in other regions of Argentina. These new lifestyles, however, were not uniform across the province of Córdoba. The various adaptations to the highland and lowland environments suggest the existence of multiple ethnic groups, contradicting claims of cultural unity made by the Spanish chroniclers (Laguens 1999; Laguens and Bonnin 2009; Pastor et al. 2013). The archaeological record also suggests that between 1000 and $500 \mathrm{BP}$ there was a deterioration in the quality of life of people coinciding with population growth and an intensive exploitation of space, which put pressure on available resources in different environments (Laguens and Bonnin 2009).

Bioarchaeological studies on health and physical activity levels show an increase in the frequency of certain diseases and biological markers of stress toward the end of the Late Holocene, in the years leading to $500 \mathrm{BP}$ (Fabra and
González 2015; Fabra et al. 2012). These likely indicate increasing environmental and social stress, resulting in the emergence of potential social conflicts over new territories for settlement and exploitation of resources (Fabra et al. 2015; Laguens and Bonnin 2009; Pastor et al. 2015).

Against the background of this larger context of research, this article offers a contribution to the study of the diet and oral health of the human populations inhabiting the central region of Argentina, particularly those who lived on the central highlands and eastern lowlands of Córdoba Province during the Late Holocene (4000-300 BP). Our analysis of stable isotopes $\left(\delta^{13} \mathrm{C}_{\mathrm{col}}, \delta^{15} \mathrm{~N}\right)$, physiological stress indicators (tooth wear), and infectious dental diseases (caries) found clear regional and temporal differentiation and a slight deterioration in oral health in the Late Holocene.

\section{Materials and Methods}

\section{Study Area}

The individuals analyzed in this study originate from central Argentina, between $30^{\circ}$ and $35^{\circ}$ south latitude and $62^{\circ}$ and $66^{\circ}$ west longitude, an area corresponding to the central highlands and eastern lowlands of Córdoba Province. The eastern pampas plains are bordered by hills to the west. Two phytogeographic regions are present: the Espinal Forest and Chaqueño Subtropical Forest, each exhibiting a predominance of Prosopis sp. (algarrobos), Schinopsis sp. (quebracho colorado), Celtis ehrenbergiana (tala), Aspidosperma quebracho-blanco (white quebracho), Ziziphus mistol (mistol), Prosopis nigra (black algarrobo), Prosopis caldenia (caldén), Schinus fasciculatus (black molle or moradillo), and several shrub species of the Acacia genus (Cabido et al. 2018). In the northern part of the region there are two major wetlands: Laguna Mar Chiquita in the northeast and Salinas Grandes in the northwest. Paleoclimatic reconstructions show an alternation between cold and dry phases, the maximum peak of which occurred at around 4700 BP (Piovano et al. 2009), and warm and humid periods, particularly in the Medieval Warm Period between 1100 and 1400 BP. This latter period coincided with 
greater population growth of the region's indigenous societies (Laguens and Bonnin 2009). The present-day climate can be defined as subtropical semiarid monsoon, with temperatures ranging from mild to warm and with generally scarce rainfall during the summer months (Osterrieth and Zucol 2000).

\section{The Sample}

In this work we analyzed the permanent dentition of 33 adult males and 16 adult females $(1,026$ teeth and 1,265 tooth sockets) from 33 archaeological sites located in the central highlands $(n=19)$ and in the eastern lowlands region $(n=14)$, in Córdoba Province (Figure 1).

The bioanthropological analyses were performed following the procedures established by Buikstra and Ubelaker (1994). For adult sex determination we considered morphological characteristics of the pelvis (the subpubic region, sciatic notch, and preauricular sulcus) and features of cranial morphology (the nuchal crest, size of the mastoid process, prominence of the glabella, and projection of chin eminence).

We dated the 49 individuals through AMS on collagen, finding a range of $4058 \pm 89$ and $370 \pm$ $15{ }^{14} \mathrm{C}$ BP. We recovered related $\delta^{13} \mathrm{C}_{\mathrm{col}}(n=35)$ and $\delta^{15} \mathrm{~N}(n=26)$ information during the dating process. This work is based on isotopic data already published, although we present nine new samples from the region (see Supplemental Table 1 for information regarding the archaeological sites from which the individuals come, the regions to which they were assigned, the chronological and isotopic data, type of material analyzed, and earlier bibliographical references).

\section{Methodology}

We consider dental caries to be a multifactorial disease stemming from the demineralization of dental tissue caused by organic acids, which are produced by oral bacteria (Lukacs 1989; Simón-Soro and Mira 2015). We recorded dental caries as present or absent and lesion location (crown, root), size, severity, and chronicity, following Buikstra and Ubelaker (1994), Hillson (2001), and Lanfranco and Eggers (2010). Lanfranco and Eggers (2010) suggest that, to account for the chronicity of carious lesions, one must record their locations (occlusal, extra-occlusal) and depths in addition to their frequencies; they claim that changes in location and depth are associated with the adoption of agriculture. Rates of dental caries were calculated by dividing the number of carious teeth by the total number of observable teeth.

There are several methods for recording and evaluating the degree of dental wear (Molnar 1971; Scott 1979). We used Smith's (1984) method, which consists of an ordinal scale with eight degrees of wear and inspection at the macroscopic level. This method allows recording of the entire dental arch and comparison with other studies because it is widely used in dental anthropology.

We analyzed the stable isotope ratios of carbon $\left(\delta^{13} \mathrm{C}_{\mathrm{col}}\right)$ and nitrogen $\left(\delta^{15} \mathrm{~N}_{\mathrm{col}}\right)$ and the ${ }^{14} \mathrm{C}$ ages, both obtained from the organic fraction of bone. The analyses were done with bone collagen and tooth dentine in the samples taken from the 49 individuals. These samples were analyzed at three facilities. First, stable isotope analysis of bone samples with MTC laboratory codes was conducted at the Graduate School of Frontier Sciences, University of Tokyo, and ${ }^{14} \mathrm{C}$-dating of the samples was done at the university with a micro analysis laboratory tandem accelerator (MALT). Collagen extraction was based on the adjusted Longin method (Longin 1971; Yoneda et al. 2002). At the second analytical facility, the KCCAMS/UCI, University of Irvine-California, we analyzed bone and dentine samples with UCI laboratory codes. Collagen extraction and graphitization were conducted following established protocols (Brown et al. 1988; Santos et al. 2004), as described in Laguens and colleagues (2009). The measurement error estimated from running standards was $0.1 \%$ or for $\delta$ ${ }^{13} \mathrm{C}_{\text {col }}$. The third facility was the Arizona AMS facility (AA laboratory code) where radiocarbon dates and reported values of $\delta^{13} \mathrm{C}_{\mathrm{col}}$ were determined. The preservation of collagen was estimated using $\mathrm{C}: \mathrm{N}$ ratios. We eliminated collagen samples with $\mathrm{C}: \mathrm{N}$ ratios outside the 2.9-3.6 range, because these samples were likely to have been exposed to diagenetic alteration (Ambrose 1990). Samples were subjected to graphitization to measure their ${ }^{14} \mathrm{C}$ dates. Unfortunately, $\mathrm{C}: \mathrm{N}$ ratios were not measured for some samples analyzed at the Arizona AMS facility. 


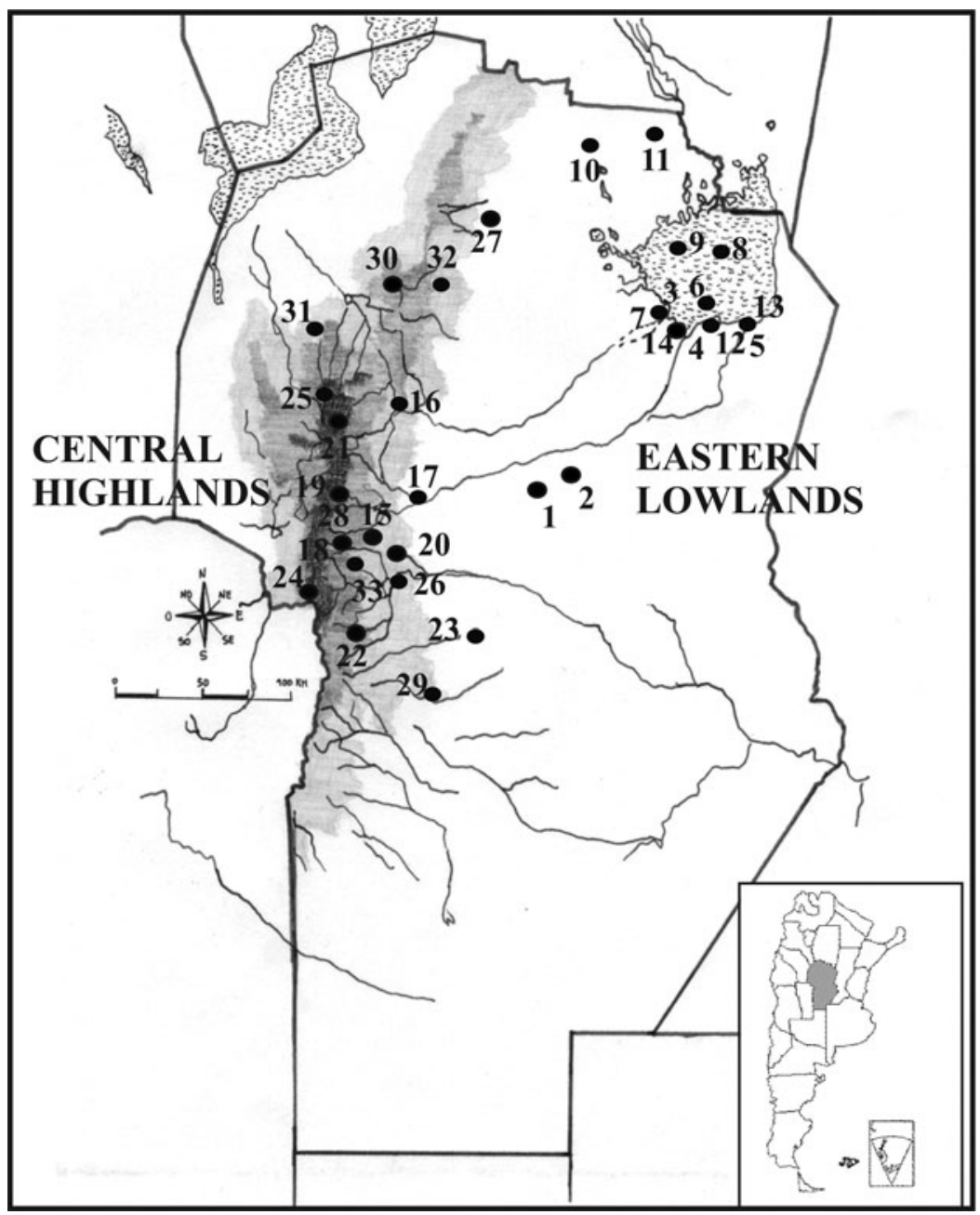

Figure 1. Geographic location of archaeological sites analyzed in this study. Eastern lowlands: (1) Costasacate, (2) Rincon, (3) Ea. La Elisa, (4) El Diquecito, (5) Colonia Muller, (6) Laguna del Plata, (7) Marull, (8) Isla Tigre, (9) EI Mistolar, (10) Laguna de la Sal, (11) Rio Dulce, (12) Orihuela, (13) Isla Orihuela, (14) La Para. Central Highlands: (15) Copina, (16) EI Vado, (17) La Granaja, (18) Cuesta Blanca, (19) Potrerillo de Larreta, (20) Los Molinos, (21) San Esteban, (22) Loma Bola, (23) Quillinzo, (24) Guasmara, (25) Rosca Yaco, (26) Banda Meridional del Lago, (27) Cerro Colorado, (28) Constantinopla, (29) Santa Rosa, (30) Ischilin, (31) Charquina, (32) Nunsacat, (33) Copina.

Given that one of the objectives of this study was to investigate the diversity of health patterns present among humans who lived in this region during the Late Holocene, it was important to consider the temporal assignation and geographical origin of the sample population. We acknowledge that the total sample size was small and that many archaeological sites are represented by only one individual; unfortunately these are the characteristics of the majority of sites in the region. We analyzed isotopic values in relation to the entire sample and made temporal and regional comparisons by sex, analyzing their correlation with the prevalence of caries and dental wear as indirect indicators of diet and health. We then compared the results with those of the isotopic ecologies of neighboring regions, particularly those of the Argentine Central West region (Gil et al. 2009). For the association of stable isotope ratios with different photosynthetic pathways, we followed Coltrain and Leavitt (2002) and Giardina and colleagues (2014). 
Individuals who consume primarily $\mathrm{C}_{3}$ resources will have $\delta{ }^{13} \mathrm{C}_{\mathrm{col}}$ values of $-21.5 \%$ on average, with a range between $-17 \%$ and $-23 \%$ o. Individuals with diets based primarily on $\mathrm{C}_{4}$ resources will have $\delta{ }^{13} \mathrm{C}_{\mathrm{col}}$ values around $-7.5 \%$, with a range between $-14 \% o$ and $-7 \%$. Values between $-17 \%$ and $-14 \%$ are considered indicative of mixed diets (Giardina et al. 2014). Finally, we applied a Mann-Whitney $U$ test to evaluate the statistical significance of the differences observed in the isotopic data, and used a chi square for dental indicators of health and diet.

\section{Results}

\section{Carious Lesions}

This pathology was registered in 41 individuals who had at least one cavity, representing $83.63 \%$ of the total surveyed; 129 caries were recorded in 1,026 teeth $(12.57 \%)$. In terms of the prevalence in the entire sample, this condition occurred more frequently in female individuals, with similar values in both time periods considered in this study. In males, we observed an increase in frequency of caries over time, being in the later Late Holocene.

The prevalence of caries lesion varied by region: it was higher in the eastern lowland region than in the central highland region in both chronological periods. This condition as a whole was more frequent in the later periods of the Late Holocene. When we considered the relationship of the sex variable to temporal and spatial location, we found that in the early Late Holocene the presence of caries in the eastern lowlands was much higher than in the central highlands, with the highest frequency exhibited in females $(23.8 \%)$. It is important to note the low prevalence of caries in the central highlands in the pre-1200 BP male and female populations and its notable increase in the later period for female individuals (Table 1).

Given these differences between geographical regions and periods, we were interested in determining the location and size of cavities in the dental structure, which would provide information regarding chronicity of the carious lesions. Before 1200 BP, caries affecting the crown $(58.06 \%)$ and large caries where the pulp cavity
Table 1. Prevalence of Caries Differentiated by Chronological Period, Region, and Sex.

\begin{tabular}{|c|c|c|c|c|}
\hline & \multicolumn{2}{|c|}{$\begin{array}{c}\text { Pre-1200 years } \\
\text { BP }\end{array}$} & \multicolumn{2}{|c|}{$\begin{array}{c}\text { Post- } 1200 \text { years } \\
\text { BP }\end{array}$} \\
\hline & $\mathrm{A} / \mathrm{O}$ & $\%$ & $\mathrm{~A} / \mathrm{O}$ & $\%$ \\
\hline \multicolumn{5}{|c|}{ Central Highlands } \\
\hline Male & $3 / 67$ & 4.47 & $37 / 341$ & 10.85 \\
\hline Female & $2 / 46$ & 4.34 & $25 / 146$ & 17.12 \\
\hline \multicolumn{5}{|c|}{ Eastern Lowlands } \\
\hline Male & $16 / 134$ & 18.05 & $25 / 171$ & 14.61 \\
\hline Female & $15 / 63$ & 23.8 & $6 / 58$ & 10.34 \\
\hline
\end{tabular}

Note: A: teeth affected, O: observed teeth, \%: prevalence.

was exposed $(22.58 \%)$ predominated, particularly in the eastern lowlands, whereas in the central highlands, those present in the pulp cavity $(80 \%)$ and, to a lesser extent, in the neck (20\%), were more frequent. In contrast, at the end of the final Late Holocene, an increased presence of caries was found outside the crown, although the crown and the pulp cavity remained the most affected surfaces in both regions. Thus, mainly in the central highlands, we observed a slight increase in caries in the crown and neck, neck and neck root, and crown and root, indicating the presence of large cavities of considerable depth. In summary, caries affecting the crown, neck, and root were more frequent in the central highlands and less frequent during the later Late Holocene in the eastern lowlands. Nevertheless, in the latter region, the presence of caries affecting the pulp cavity was directly related to the high degree of tooth wear recorded in later times (Figure 2).

\section{Dental Wear}

Occlusal dental tooth wear was registered in 1,021 teeth (40 individuals). Degree 6 of dental wear, following the ordinal scale proposed by Smith (1984), was the most represented $(21.84 \%)$ for all teeth, whereas degree 5 was the second most represented $(19.78 \%)$. We suggest that more than half $(761 / 1021 ; 74.53 \%)$ of the samples have moderate to severe dentin exposure (grades 5-8). The remaining 260 samples ( $25.46 \%$ of the total sample) exhibit low to moderate dentin exposure (grades 1-4).

If we look at the distribution of the degrees of tooth wear while considering the sex of 


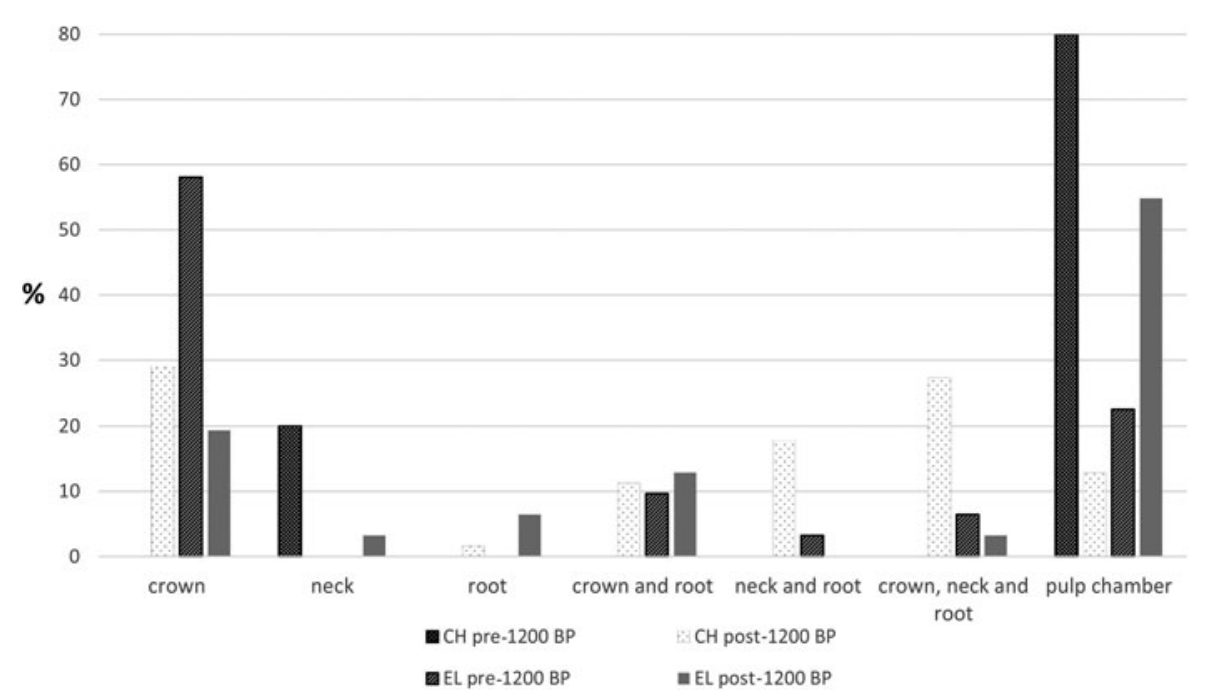

Figure 2. Frequency of caries according to the location in the tooth.

individuals, we observe that females present more advanced dental wear than males. In terms of geography, the eastern lowland region presents higher degrees of dental wear. Regarding the chronological periods, there is a higher incidence of dental wear before 1200 BP (González and Fabra 2018). Finally, when we consider what happens with individuals according to sex, regional provenance, and chronology, we note that in both regions the highest degrees of wear are present at early times, in both males and females (Figure 3). In the central highlands, in the earlier period, both males and females have similarly high rates of severe wear (grades 6 and 7 ), with moderate grades being mostly present in females. It should be noted that females in this period exhibit greater frequencies of grade 8 wear, the most severe level of wear. In later times, we observed the presence of all grades of wear, especially grades 4-6. Moreover, in the eastern lowlands in early times, there is a high prevalence of severe wear (grades 6-8) in both males and females. In later times, the degrees of wear are extended, with all grades being present and a higher prevalence of severe grades in males.

\section{Stable Carbon Isotopes}

Table 1 shows $\delta^{13} \mathrm{C}_{\mathrm{col}}$ and $\delta^{15} \mathrm{~N}$ isotope ratios for each of the samples (also see Supplemental Table 1 and Supplemental Text 1). All samples show adequate $\mathrm{C} / \mathrm{N}$ ratios. The range of variation of carbon isotope ratios is between -18.0 and $-10.4 \%$, with an average of $-14.4 \pm 2.2 \%$ o for $\delta^{13} \mathrm{C}_{\mathrm{col}}$. The range of variation of nitrogen isotopes is between $2.7 \%$ and $3.3 \%$, with an average of $3.0 \pm 0.3 \%$ for $\delta^{15} \mathrm{~N}$. In the early Late Holocene (before $1200 \mathrm{BP}$ ), similar isotopic ratios are shown in both areas. Individuals from the central highlands have carbon isotope ratios between $-18.0 \%$ ond $-10.4 \%$, with average values and standard deviation of $-16.9 \pm 1.0 \%$ o for $\delta^{13} \mathrm{C}_{\mathrm{col}}(n=3)$ and $7.9 \pm 0.6 \%$ for $\delta^{15} \mathrm{~N}$ $(n=2)$. Individuals of the eastern lowlands have carbon isotope ratios between $13.7 \%$ and $-17.3 \%$, with an average of $-15.5 \pm 1.8 \%$ o $(n=10)$. The only nitrogen sample has a value of $\delta^{15} \mathrm{~N}$ of $9.4 \%$. There is no statistical difference in carbon isotope ratios between regions in early Late Holocene times ( $p=0.400$ for $\delta^{13} \mathrm{C}_{\mathrm{col}}$; the $\delta^{15} \mathrm{~N}$ sample is too small to subject to statistical tests).

The two regions begin to exhibit dietary variation after 1200 BP. Carbon isotopic ratios of the central highlands range between $-10.4 \%$ and $-17.7 \%$, with an average of $-13.2 \pm 2.3 \%$ o $(n=19)$. This is statistically higher than the values from the eastern lowlands, which exhibit a range from $-11.8 \%$ o to $-17 \%$ and an average of $-15.0 \pm 1.5 \%$ o $(n=17 ; p=0.032)$. There are also statistical differences $(p=0.049)$ in nitrogen isotopic ratios. The central highlands range from 


\section{Central Highlands}

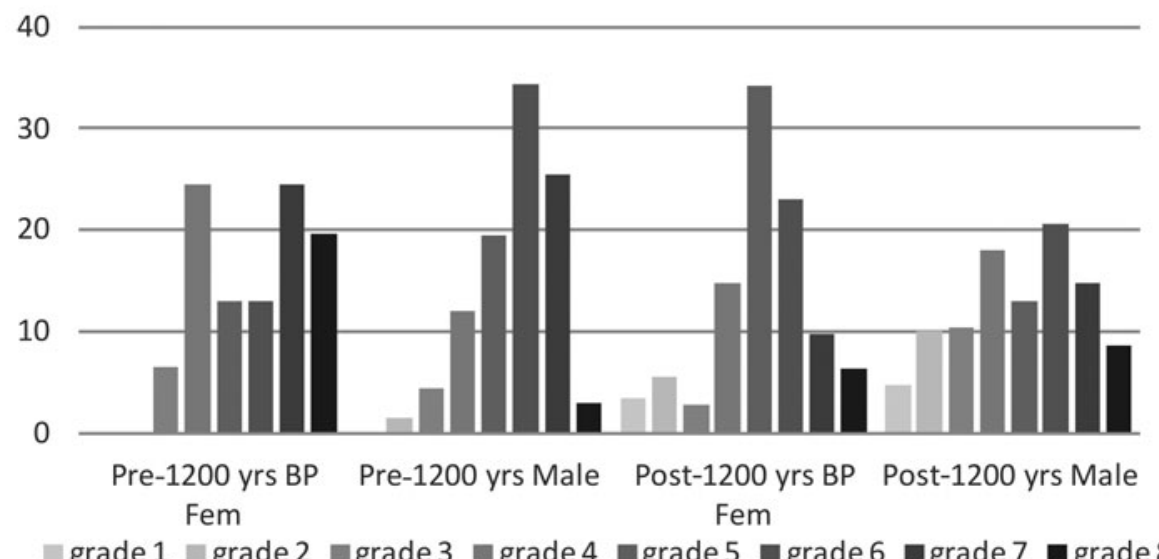

\section{Eastern Lowlands}

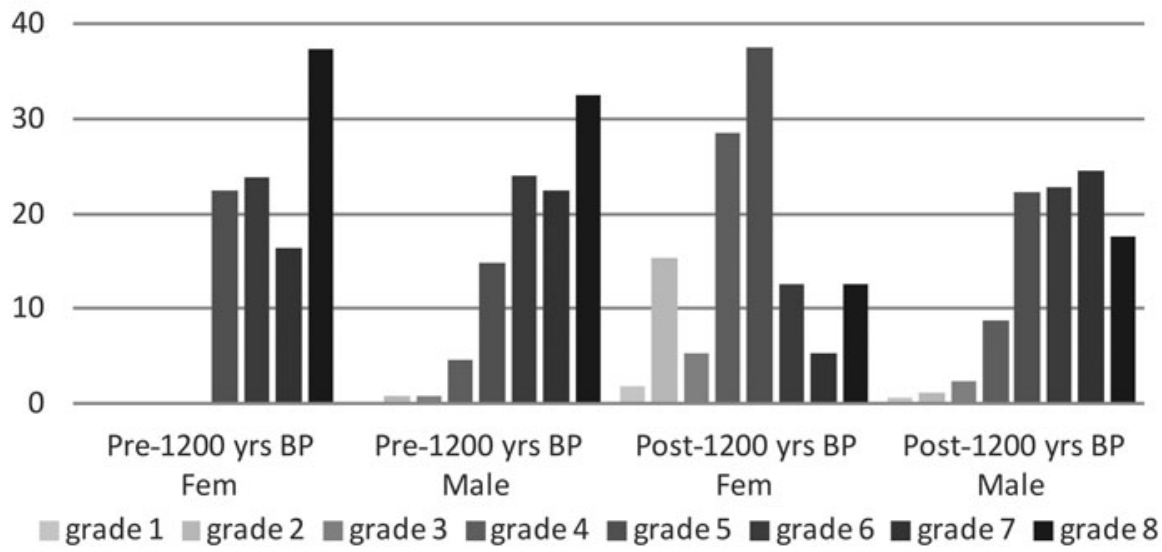

Figure 3. Degree of tooth wear in central highlands and eastern lowlands; grades 1-8 correspond to the degree of dental wear according to Smith (1984).

$8.3 \%$ o to $11.5 \%$, with an average of $9.1 \pm 1.3 \%$ o $(n=13)$. The eastern lowlands range from $7.9 \%$ o to $12.9 \%$, with an average of $10.4 \pm$ $1.7 \%$ o $(n=10$; Table 2$)$.

These isotopic variations also suggest changes in diet through time. Carbon isotope ratios are elevated only in the central highlands ( $p=0.023$ in the central highlands and $p=$ 0.800 in the eastern lowlands). These results mean that $\mathrm{C}_{4}$ resources were more frequently consumed in the central highlands after 1200 $\mathrm{BP}$, in contrast to the eastern lowlands, which exhibit more $\mathrm{C}_{4}$ resource consumption before $1200 \mathrm{BP}$.
Figure 4 shows ratios of $\delta^{13} \mathrm{C}_{\mathrm{col}}$, considering the temporal distribution of each sample in the central highlands and in the eastern lowlands. In the eastern lowlands, ranges of isotopic data before $1200 \mathrm{BP}$ are higher than those in later times. Although there are no statistically significant changes in diet through time in the eastern lowlands, the oldest sample shows reliance on $\mathrm{C}_{3}$ resources. In this region, $\mathrm{C}_{4}$ resources exploitation appears after $2000 \mathrm{BP}$. The exact timing of the increase in the exploitation of $\mathrm{C}_{4}$ resources is still uncertain and would provide fruitful grounds for a future study of the early Late Holocene. 
Comparison by sex indicates no statistical differences. For the central highlands after $1200 \mathrm{BP}$, the $\delta^{13} \mathrm{C}_{\mathrm{col}}$ sample, composed of 4 females and 12 males, has a $p$-value of 0.446 . The $\delta^{15} \mathrm{~N}$ sample, consisting of 3 females and 10 males, has a $p$-value of 0.112. For the eastern lowlands after $1200 \mathrm{BP}$, the $\delta^{13} \mathrm{C}_{\mathrm{col}}$ sample, consisting of 4 females and 9 males, has a $p$-value of 0.710 . The $\delta^{15} \mathrm{~N}$ sample, consisting of 4 females and 8 males, has a $p$-value of 0.178 . The sample size is too small to analyze statistically meaningful differences of $\delta^{13} \mathrm{C}_{\mathrm{col}}$ and $\delta^{15} \mathrm{~N}$ values in the central highlands and eastern lowlands before 1200 BP. The highest nitrogen isotope ratios are found in the eastern lowlands, but most samples generally show low values, and we observed no meaningful regional or temporal variation (Figure 5).

Unfortunately, no information is available about the isotopic ecology of both regions, making it difficult to interpret the values obtained, both those pertaining to each individual and those for the whole sample. Despite this lack of information, we elected to compare the isotopic values of carbon and nitrogen from the data presented here with data obtained from the isotopic ecology of the midwestern region of Argentina, which has climatic and environmental conditions similar to those in Córdoba (Ehleringer et al. 1997; Giardina et al. 2014; Gil et al. 2006; Martínez et al. 2009; Supplemental Table 2, Figure 6).

We observed that the values of all $\delta^{13} \mathrm{C}_{\mathrm{col}}$ human bone samples are grouped between -10.6 and $-18 \%$, and the values of $\delta^{15} \mathrm{~N}$ are grouped between 7.4 and $12.9 \%$. This suggests that there is variability in the consumption of resources, with a relative incorporation of both $\mathrm{C}_{4}$ food resources and of animal resources for both regions. This variability is best represented if we compare isotopic ratios for each region: samples of the central highlands have values similar to those found in $\mathrm{C}_{4}$-type resources, with $\delta^{13} \mathrm{C}_{\text {col }}$ averaging to $-13.8 \%$ and $\delta^{15} \mathrm{~N}$ ratios averaging to $9.0 \%$. In the eastern lowlands, ratios of $\delta^{13} \mathrm{C}_{\mathrm{col}}$ are higher (average $-15.1 \%$ ), and $\delta^{15} \mathrm{~N}$ is more enriched (average $10.3 \%$ ). When the isotopic ratios obtained from each individual are compared to those of animal and plant data in the existing literature, 


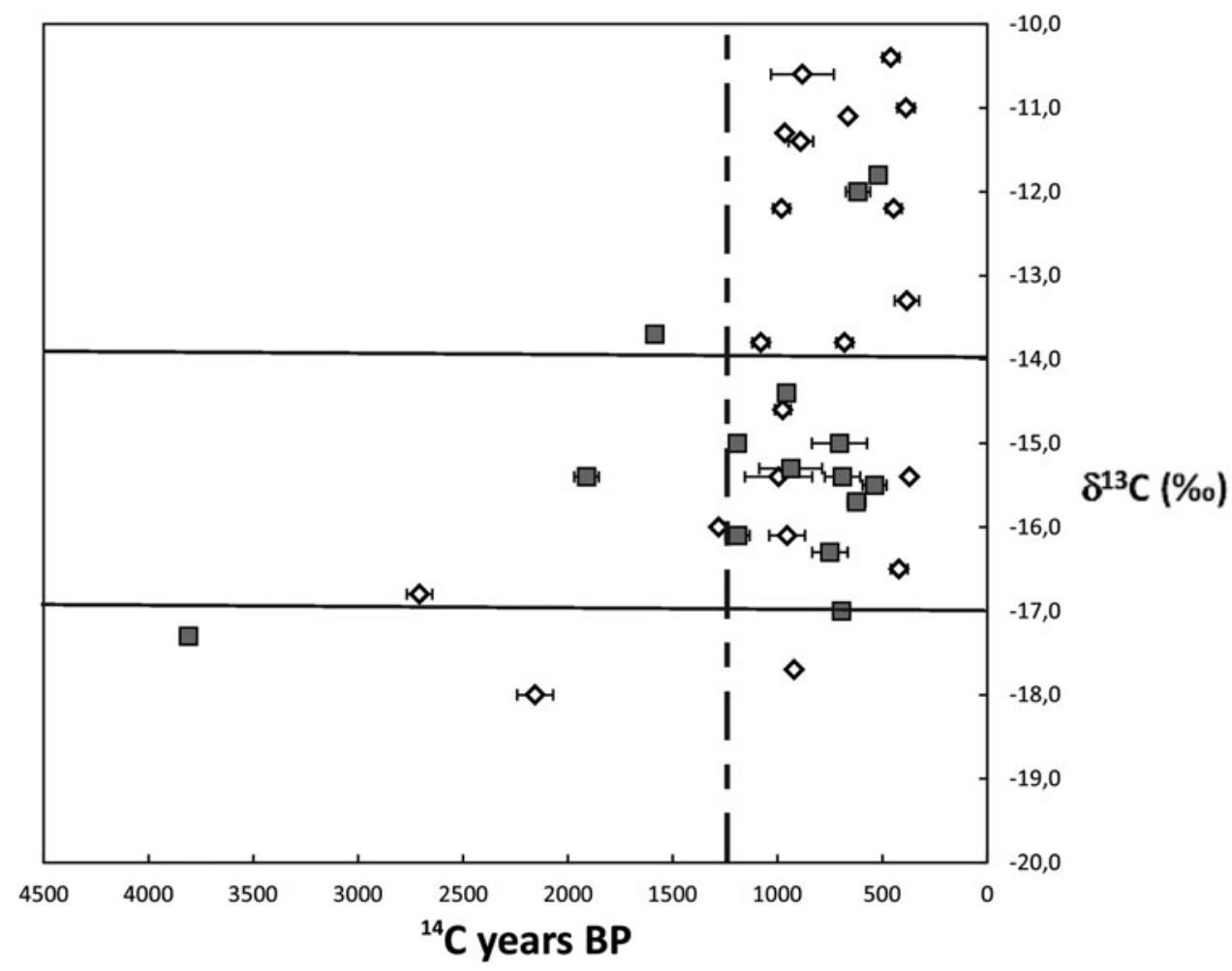

Figure 4. Average $\delta^{13} \mathrm{C}_{\mathrm{col}}$ isotopic values of bone samples considering region and chronology. Legend: square: eastern lowlands; rhombuses: central highlands; dotted line: temporary dividing line separating pre- and post-1200 years BP; solid lines: division between isotopic types of diets according to Giardina and colleagues (2014) and Coltrain and Leavitt (2002).

individuals from the eastern lowlands have values closer to those in $\mathrm{C}_{3^{-}}$- type resources and enriched nitrogen values, which could be associated with the consumption of faunal resources of lacustrine origin, such as fish, waterfowl, and possibly rodents.

By comparing the entire sample with animal and plant resources, when we consider average values for $\delta^{15} \mathrm{~N}$, we note that the overall average has values even higher than herbivores potentially consumed by these populations (4.3\%o and $5.7 \%$, average $4.9 \%$ ); they are closer to the values provided by other mammals, including species of rodents or Chinchillidae, and other mammals such as Dasypodidae (4.5\%o and $10.8 \%$, average $8.15 \%$ o) and omnivorous mammals/carnivores like Conepatus chinga, Lycalopex griseus, and Leopardus geoffroyi that have similar $\delta^{15} \mathrm{~N}$ ratios, between 6.2 and $8.1 \%$ o (Figure 6). The most enriched values in our sample, higher than $10.5 \%$, correspond to individuals who inhabited the eastern lowlands, particularly in the coastal sites of the lagoon of Mar Chiquita, in the period after 1200 BP. We suggest that these populations consumed, among other foodstuffs, poultry and fish (Cathartes aura, Cocoroba coscoroba, and Anatidae) that present average values of nitrogen of $12.3 \%$ o (Giardina et al. 2014) and other resources such as Lycalopex griseus, Chinchillidae, and Rhea americana. Individuals of the eastern lowlands present more enriched values of $\delta^{13} \mathrm{C}_{\mathrm{col}}$, but in a more limited range than the individuals of the central highlands, which brings them closer to the consumption of $\mathrm{C}_{4}$ resources, such as maize, herbivores such as Lama sp., or carnivores such as Leopardus geoffroyi.

Finally, we were interested in comparing the isotopic ratios, discussed in the preceding paragraphs, with those resulting from dental 


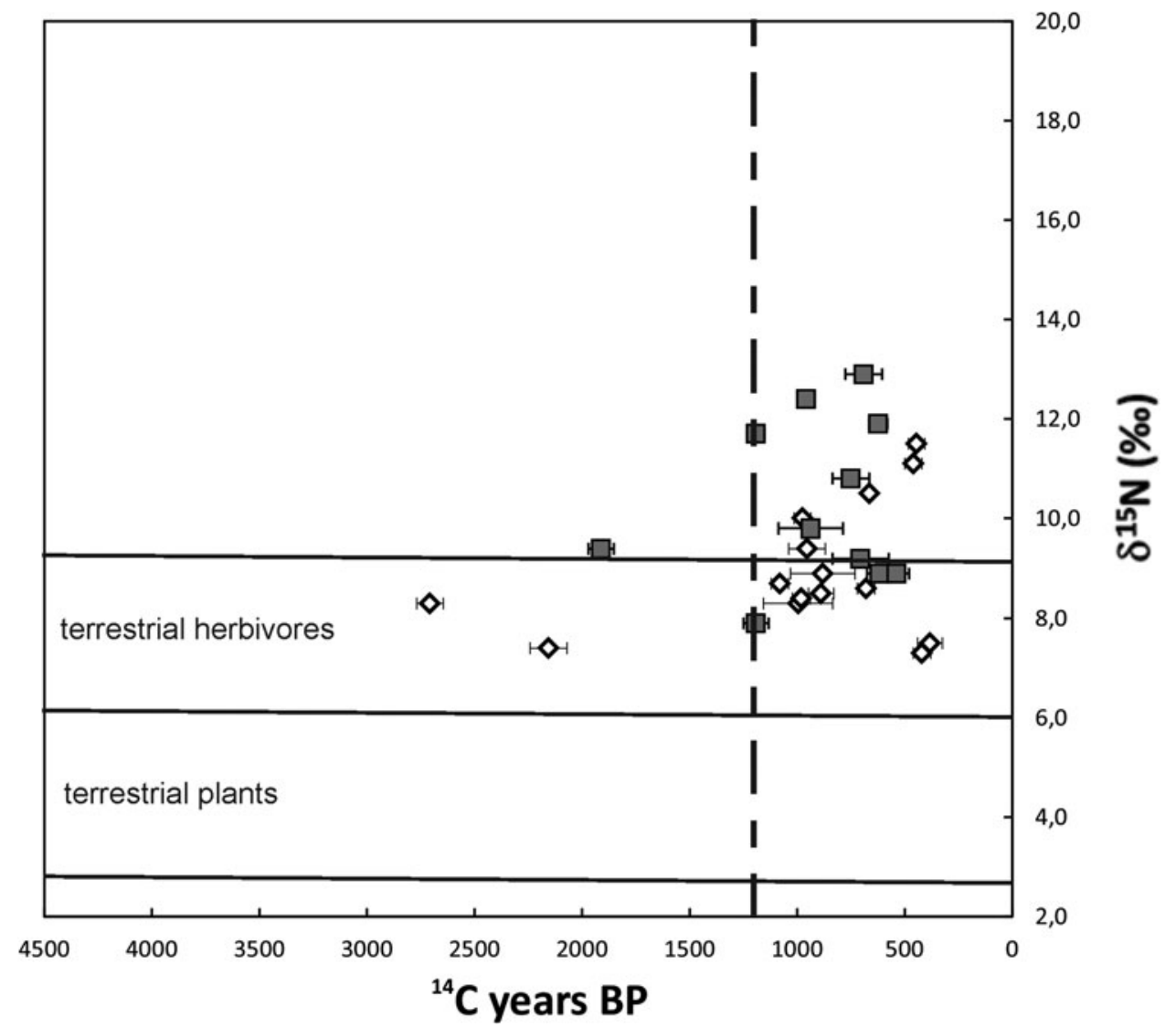

Figure 5. Average $\delta^{15} \mathrm{~N}$ isotopic values of bone samples considering region and chronology. Legend: square: eastern lowlands; rhombuses: central highlands; dotted line: temporary dividing line separating pre- and post-1200 years BP; solid lines: division between isotopic types of diets according Giardina and colleagues (2014) and Coltrain and Leavitt (2002). It should be noted that both the nitrogen values of herbivores and terrestrial plants are enriched in arid and saline soils (Pate 1994).

indicators related to diet, such as dental caries and tooth wear (Table 3 ). Both the overall average carbon isotope $\delta^{13} \mathrm{C}_{\mathrm{col}}(-14.4 \%$ ) and the prevalence of caries for the whole sample $(12.75 \%)$ are consistent with those expected for populations that have incorporated resources like corn; in such populations, the consumption of resources derived from hunting and gathering prevails (Coltrain and Leavitt 2002; Pate 1994; Turner 1979). When assessing the presence of this pathology by region, we observed, in the central highlands, a low prevalence of caries before $1200 \mathrm{BP}$ in both females and males, in contrast to what was observed during the same period in the eastern lowlands. For both regions and sexes, the values of $\delta^{13} \mathrm{C}_{\mathrm{col}}$ are slightly more impoverished before $1200 \mathrm{BP}$.
We considered the presence of tooth wear as a factor that affects the number of caries, especially in the central highlands. Even though average tooth wear is shown to be high at the very beginning of the Late Holocene, it is in the eastern lowlands where the greatest presence of advanced tooth wear is observed, accompanied by a high prevalence of caries. This suggests that such an indicator does not significantly affect the presence of this pathology. The major changes-the increased prevalence of caries and the most positive isotopic values for both sexes-are noted in the central highlands during the later Late Holocene, which could indicate the addition of novel food to the dietary habits. Figure 4 shows that individuals in this region have 


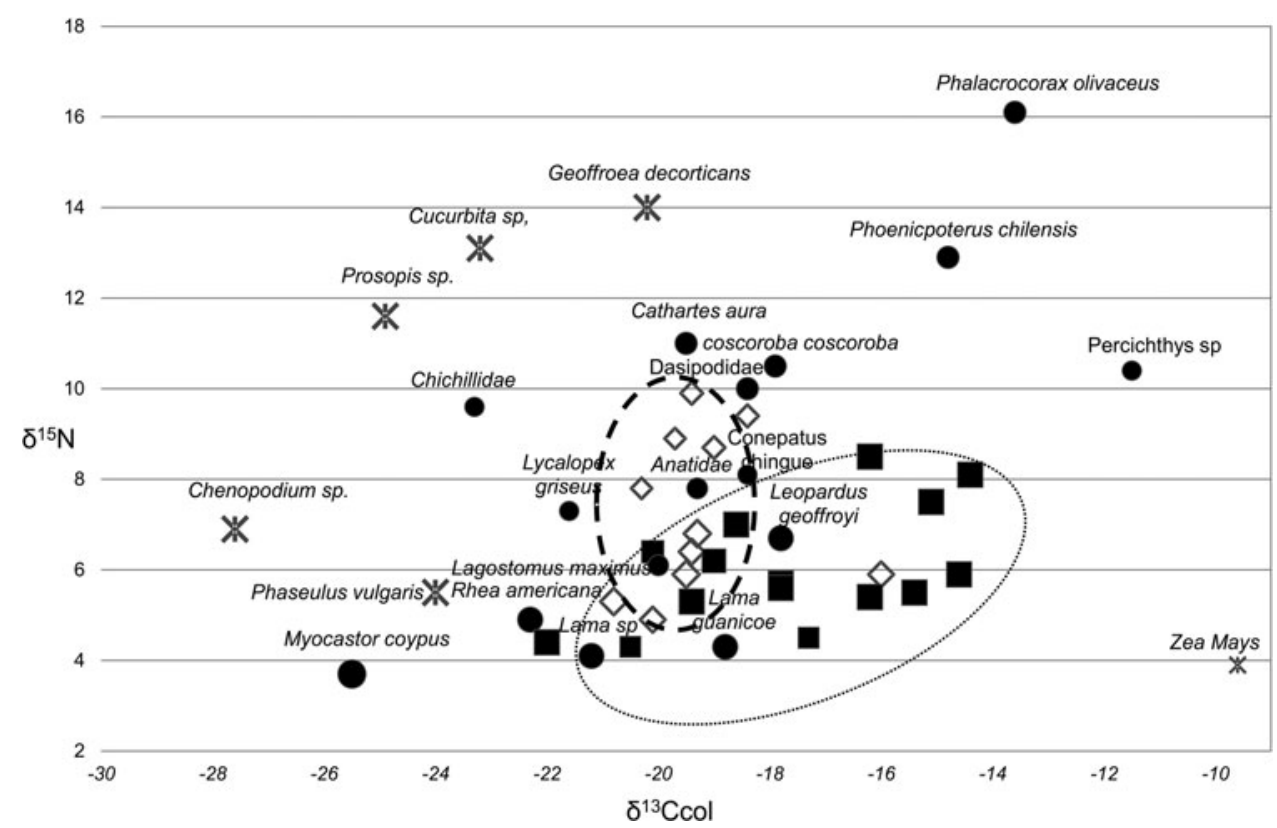

Figure 6. Isotope ratios of $\delta^{13} \mathrm{C}_{\mathrm{col}}$ and $\delta^{15} \mathrm{~N}$ of bone samples divided by region and potentially consumable vegetal and faunal resources (according to Giardina et al. [2014] and Gil et al. [2006]). Legend: black squares: central highlands; white rhombuses: eastern lowlands; stars: vegetable resources; circles: faunal resources; oval thick dot: highest concentration of eastern lowlands individuals; fine dotted oval: highest concentration of central highlands individuals. Faunal isotopes were corrected $-2.3 \%$ for $\delta^{13} C_{c o l}$ and $-0.8 \%$ for $\delta^{15} \mathrm{~N}$ following Tieszen and Fagre (1993) and Ambrose (2000). Human remains were corrected $-4 \%$ for $\delta^{13} \mathrm{C}_{\text {col }}$ and $-3 \%$ for $\delta^{15} \mathrm{~N}$ following Ambrose (1993), Ambrose and Norr (1993), DeNiro and Epstein (1981), and Schoeninger and DeNiro (1984).

more $\delta^{13} \mathrm{C}_{\mathrm{col}}$ values below $-14 \%$, suggesting that more individuals in the central highlands consumed cultivated resources compared to those in the eastern lowlands.

Significant results were observed in the case of dental wear. This continuous variable is inherently difficult to quantify. We therefore transformed it into a binary variable, assigning groups one of two values for subsequent statistical treatment. Samples with values lower than degree 4 were placed in one group, and samples with values higher than 5 in another, following Smith's (1984) scale. We observed significant differences by region: in the eastern lowlands the prevalence of advanced wear is higher $(p=0.02)$.

Table 3. Comparison between Average Isotope Values of $\delta^{13} \mathrm{C}_{\mathrm{col}}$ and $\delta^{15} \mathrm{~N}$ and Prevalence of Caries and Average Dental Wear according to Chronological Period, Region, and Sex of the Samples.

\begin{tabular}{|c|c|c|c|c|c|c|}
\hline & \multicolumn{3}{|c|}{ Pre-1200 Years BP } & \multicolumn{3}{|c|}{ Post-1200 Years BP } \\
\hline & \multicolumn{6}{|c|}{ Central Highlands } \\
\hline & Caries\%/ P/d & $\delta^{13} \mathrm{C} \% o$ & $\delta^{15} \mathrm{~N} \%$ & Caries $\% / \mathrm{P} / \mathrm{d}$ & $\delta^{13} \mathrm{C} \%$ & $\delta^{15} \mathrm{~N} \%$ \\
\hline Female & $4.34 / 6.15$ & -17 & 7.8 & $17.12 / 5.23$ & 13.5 & 8.6 \\
\hline \multirow[t]{3}{*}{ Male } & $4.47 / 5.54$ & -14.3 & 8.8 & $10.85 / 4.78$ & 13.5 & 10.5 \\
\hline & \multicolumn{6}{|c|}{ Eastern Lowlands } \\
\hline & Caries \% P/d & $\delta^{13} \mathrm{C} \%$ & $\delta^{15} \mathrm{~N} \% o$ & Caries $\% \mathrm{P} / \mathrm{d}$ & $\delta^{13} \mathrm{C} \%$ & $\delta^{15} \mathrm{~N} \% o$ \\
\hline Female & $23.8 / 6.64$ & -14.9 & 9.4 & $10.34 / 5.19$ & -13.9 & 8.9 \\
\hline Male & $18.05 / 6.69$ & -15.8 & 10 & $14.61 / 6.18$ & -15.4 & 11.2 \\
\hline
\end{tabular}

Note: \% prevalence; P/d: average wear. 


\section{Discussion and Conclusion}

The moderate prevalence of caries in the sample in the two periods of the Holocene is consistent with the expected values for hunter-gatherer populations or for those with a mixed economy (Lukacs 1989). During this time, human groups made changes to their subsistence strategies, but differences were not statistically significant between the two periods. This pathology was present in both sexes from the early Late Holocene, although it was more frequent in females in the centuries preceding the Spanish conquest (González 2016).

Regarding the size and location of the caries, it is interesting to note that in females in the central highlands, we observed an increased presence of large cavities affecting the crown, neck, and root, a pattern associated with foods that are rich in sucrose and starches that increase the growth of plaque and bacteria in the mouth (Lanfranco and Eggers 2010). In the eastern lowlands, there were more frequent cavities affecting the pulp cavity, caused largely by advanced tooth wear recorded in this region; males were most affected by this type of condition. These results would suggest, first, the consumption of cariogenic food at the beginning of the Late Holocene and an increase in that consumption in the later years of the Late Holocene, particularly in the central highlands; this increase is possibly associated with horticulturalist practices. The isotopic data support this trend. In general, the existence of carious pathology is associated with the consumption of food rich in sugars and carbohydrates, such as maize (Cuccina and Tiesler 2003). We should note that eating other types of food such as green beans carob (Prosopis sp.), mistols fruit (Ziziphus mistol), and chañar (Geoffroea decorticans), which may have been collected in the region, can result in the same pathology because of their high percentage of sugars and carbohydrates (Lanfranco and Eggers 2010; L'Heureaux 2000; Novellino et al. 2004), as reported in bioarchaeological investigations in other regions (Bernal et al. 2007; Gil 2003; Novellino et al. 2004).

In central Argentina, the most direct evidence of horticultural practices has been provided by archaeobotany. Pastor (2007), Lopez (2015), and Medina and colleagues (2009) have recovered evidence from several cultigens in the central highlands, such as maize (Zea mays), pumpkin (Cucurbita sp.), beans (Phaseolus vulgaris), and quinoa and amaranth (Chenopodium spp. spp./ Amaranthus). More recently, Tavarone and colleagues (2019) have detected micro-remains of Phaseolus sp., Zea mays, and Cucurbita maxima in dental calculus, dated between $1192-937{ }^{14} \mathrm{C}$ BP. The presence and possible management of species, such as Chenopodium spp. and Amaranthus spp., collected in grinding materials have dated to the beginnings of the Late Holocene (Lopez et al. 2015). Moreover, ethnohistorical documents have reported the presence of cornfields and farms near houses or scattered in different parts of the central highlands, away from settlement sites. There are several sources dating from the sixteenth and seventeenth centuries that refer to crops such as corn, squash, bean, and even quinoa (Huamiltocto, in Piana de Cuesta 1992; Sotelo de Narváez 1583).

Interestingly, we observed temporal differences in the frequency of carious lesions, particularly in the central highlands, by the end of the Late Holocene. We interpret these differences as a change in the type of resources consumed in those later times, related to the introduction of new types of food such as maize. The archaeobotanical record contributes substantially to the discussion of the presence of cultigens such as pumpkins, beans, quinoa, and corn from 3000 BP (Pastor et al. 2012) and their intensification toward 1200-1100 BP. To identify what food might have caused carious diseases and to evaluate the importance of their consumption, we must make use of isotopic evidence. In our study area there are several edible wild $\mathrm{C}_{3}$ plants, including the fruits of the carob tree (Prosopis sp.) and chañar (Geoffroea decoticans). Among cultivated vegetables, we can include pumpkin (Cucurbita sp.) and beans (Phaseolus sp.). Maize is one of the few plants with $\mathrm{C}_{4}$-type photosynthesis, along with amaranth (Amaranthus caudatus). Relatively high frequencies of amaranth have been found in later Late Holocene archaeological sites (Medina et al. 2008), suggesting that they come from farms and not from wild species (Lopez et al. 2015). The results of the isotopes of $\delta^{13} \mathrm{C}_{\mathrm{col}}$ and $\delta^{15} \mathrm{~N}$ indicate that, throughout 
the Holocene, these populations, particularly those in the central highlands, based their livelihood strategies on a broad range of resources that they collected-essentially those with a photosynthetic pattern typical of $\mathrm{C}_{3}$ food, $\mathrm{C}_{4}$ plants, and, to a lesser extent, herbivores and consumers of $\mathrm{C}_{4}$ plants. In Córdoba there is no evidence of domestication of camelids. Additionally, no wild camelids strongly dependent on $\mathrm{C}_{4}$ plants have been reported (Barberena et al. 2009).

If we consider the time scale, the picture is more complex: before $1200 \mathrm{BP}$, the higher values for $\delta^{13} \mathrm{C}_{\mathrm{col}}$, between -17.3 and $-15.4 \%$, would indicate an economy mainly based on $\mathrm{C}_{3}$-type food. Given that consumable resources with a $\mathrm{C}_{3}$ photosynthetic pattern were likely found in this region, we can include the fruits of the carob, chañar, and piquillín; herbivores like guanaco and rhea; and eggs, which based on earlier reports, would have been part of the dietary corpus of these populations ( $\mathrm{Ri}$ vero and Medina 2016; Rivero et al. 2010). We must also consider the consumption of cultivated vegetables such as Phaseolus vulgaris, which uses the $\mathrm{C}_{3}$ photosynthetic path (Tavarone et al. 2019). Yet, after $1200 \mathrm{BP}$, isotopic values for $\delta^{13} \mathrm{C}_{\mathrm{col}}$ are substantially modified, indicating more positive values in the range of $-14.7 \%$ o and $-14.1 \%$ o for both regions. These values would indicate a change in the dietary pattern of these populations, which is in agreement with the archaeological record that shows the partial incorporation of maize, particularly in the central highlands (Laguens et al. 2009; Medina et al. 2014).

In nearby regions, the incorporation of cultivated vegetables, particularly maize, was similar to the process observed in Córdoba. In the center-west of Argentina, at the southern limit of prehispanic Andean agriculture, human diets were very varied. Some sites show continuity in isotopic signals and craniofacial morphology throughout the Holocene, whereas others suggest growing maize consumption, although it remains less than $30 \%$ of the diet (Gil et al. 2017). Toward the east, in the delta of the Paraná River, populations developed strategies based on hunting, gathering, and horticulture, including the consumption of $\mathrm{C}_{3}$ vegetables (Bonomo et al. 2017). The introduction of maize to the diet would have occurred around $1000 \mathrm{BP}$, as evidenced by the archaeobotanical record of the Los Tres Gansos site 1 (Colobig et al. 2015). Subsequently, the archaeobotanical record of maize in Guarani sites shows that the population began consuming it around $700 \mathrm{BP}$ (Loponte and Acosta 2007).

Regional differences in dental wear among male individuals were detected, with more severe tooth wear in the eastern lowlands. In the central highlands females had the higher prevalence of serious wear. We believe that the difference between regions can be attributed to several factors operating simultaneously. First, a more abrasive diet could account for these differences, and different forms of cooking/food preparation may have influenced the advanced tooth wear recorded in the plains.

We are well aware of the positive relation between the advances of age, dental wear, cavities, and other types of diseases such as periapical lesions and periodontal disease. However, because of the scarce quantity of samples predating $1200 \mathrm{BP}$, we decided not to present those data because they did not yield results reliable enough to make comparisons (for a fuller discussion on this topic, see González and Fabra 2018).

In the eastern lowlands there have been found large underground pit storage areas for fruit and other resources, commonly referred to as "small ovens" or "botijas"; they were probably also used for food preparation (Cornero et al. 2013; Fabra et al. 2008; Laguens and Bonnin 2009). The deposits found in the eastern lowlands indicate that their walls were altered with heat, which could indicate uses involving high temperatures (Fabra et al. 2008). Metráux (1996) reports, for the Chaco region, the use of similar structures, where fish and other types of food were stored in underground wells that had dried up. Such structures were also found in places close to the Mar Chiquita lagoon, southeast of Santiago del Estero, which suggests a possible shared practice among these people. Hence, the intake of fibrous foods, in addition to cooking techniques such as drying or salting, and the possible incorporation of external abrasive particles, may have contributed to increased rates of occlusal wear in this region (González and Fabra 2018). 
In contrast, the presence of moderate degrees of tooth wear in the central highlands after 1200 BP could be related to the consumption of softer food or be caused by cooking techniques that facilitate intake. On the basis of the different characteristics of ceramic types found in the central highlands, Lopez and coworkers (2015) suggest ways of cooking-including boiling and preparation of stews, in addition to roasting - as usual practices after $1200 \mathrm{BP}$, which would have facilitated the digestibility of food and therefore would reduce biting pressure.

After an analysis of all these indicators, we argue that caries in the eastern lowlands caries have a moderate presence in the early Late Holocene, with a higher frequency by the end of this period. The degree of tooth wear in this region also exhibits higher variability than in the central highlands. If we consider these data, along with the archaeobotanical evidence from the region (Tavarone et al. 2019), this pattern reveals the consumption of cariogenic food, particularly gathered fruit, and the consumption of some cultivated products, such as Cucurbita maxima, which has a $\mathrm{C}_{3}$ photosynthetic path. Ethnohistorical and archaeological data, especially $\delta^{13} \mathrm{C}_{\mathrm{col}}$ and nitrogen $\delta^{15} \mathrm{~N}$ values, suggest that the populations settled in the eastern plains ate more $\mathrm{C}_{3}$-type resources and had a higher intake of animal protein, especially in the early Late Holocene, than neighboring populations (Laguens and Bonnin 2009; Laguens et al. 2009). At around $1500 \mathrm{BP}$, the population incorporated a new technology, characterized by the production of ceramic artifacts on basketry. This innovation is found in many coastal sites near the Mar Chiquita lagoon and was probably linked to new ways of producing food (Bonofiglio 2010), although data are still scant on wildlife resources exploited by these populations. If we consider $\delta^{15} \mathrm{~N}$, males would have consumed higher animal protein content than females and possibly enriched these values by their lacustrine way of life (Giardina et al. 2014).

The subsistence strategy that prevailed in the central mountains was based on hunting and gathering, with a low consumption of cariogenic vegetables. In contrast, in the plains of northeast Córdoba Province, the prevalence of caries indicates a greater reliance on vegetables with high sugar and carbohydrate content and perhaps an earlier incorporation of products grown on a small scale. In the central highlands, the archaeobotanical record indicates the presence of plant resources grown and harvested from the early Late Holocene onward (Lopez et al. 2015). At the end of the first millennium, archaeological evidence is conclusive regarding the increased presence of cultivated plants, such as pumpkins, quinoa and beans, and maize (Laguens and Bonnin 2009). Cavities of populations in the central highlands are bigger and deeper than those from individuals in the eastern lowlands (Fabra and González 2015; González and Fabra 2011); this pattern is especially evident in female individuals after 1200 BP. Thus, we suggest that populations that inhabited the mountainous region were consuming more food rich in sugar and carbohydrates, probably $\mathrm{C}_{4}$ resources and specifically maize, to supplement their dietary resources. We believe that horticultural practices were incorporated more fully in the central highlands than in the eastern lowlands, as a complement to the practice of hunting and gathering.

The differences between both regions may be related to the adaptation to the lacustrine environment by the populations that occupied the southern coast of the Mar Chiquita lagoon. A similar pattern was observed in a saline lagoon in the midwestern region of Argentina (Giardina et al. 2014), where scholars proposed that guanaco was of low importance to the overall diet and aquatic resources and small terrestrial animals were of medium importance. This is the same pattern observed in the eastern lowlands. We wonder whether the late effective introduction of food production in this region could be related to the increased availability of wild and lacustrine resources. This region was a transitional space between the phytogeographic provinces of Espinal and Chaco (Luti et al. 1979). Alternatively, the late adoption of horticulture could be linked to other cultural factors, such as a preference for certain resources or a similarity with the lifestyle of neighboring regions such as Chaco (Laguens and Bonnin 2009). As mentioned by Bonomo and colleagues (2017), the consumption of maize by the Goya-Malabrigo may have been related to symbolic spheres, because beverages 
made from fermented corn were consumed during certain festivities.

Given the bioarchaeological indicators and isotopic and archaeological evidence presented in this article (Laguens 1999; Lopez et al. 2015), we propose that food production should be considered as a complementary economic activity in a society where wild resources have greater preponderance than that generally attributed. We believe that collecting wild fruits, mainly carob and chañar, is a practice with continuity through time; this method of subsistence is of particular importance from at least 3000 years BP (Fabra and González 2015; Laguens 1999; Laguens and Bonnin 2009; Laguens et al. 2009). This practice would have been a highly effective subsistence strategy at a time where the population may have been suffering from episodes of stress caused by population growth, resource scarcity, environmental pressure, or even the arrival of the Spaniards. Each of these circumstances would have disrupted the way of life of these groups (Fabra and González 2015; Laguens and Bonnin 2009). Ethnohistorical research (Castro Olañeta 2002, 2006) has suggested that the practice of collecting carob and other wild fruits continued several centuries after the arrival of the Spaniards, serving as an element of cohesion and integration of these populations against the Spanish system.

Acknowledgments. We would like to thank all the museums responsible not only for the collections they host but also for the value they place on them and for their commitment to care for the regional bioarchaeological heritage. We especially thank Dr. Minoru Yoneda, Dr. Hiroyuki Matsuzaki, and Dr. Mai Takigami for preparing the radiocarbon dates at the Graduate School of Frontier Sciences, University of Tokyo. We are grateful to Mai Takigami for her support in statistical analysis and contributions to the analysis of isotopic data. This work was supported by these grants: FONCyT PICT 2013-2028, PICT 2015-3155, and SECyT-UNC 2014-2015. This article is based on the PhD dissertation of C. González. We would like to thank Carolina Mosconi and the Latin American Antiquity editors for their careful revision of the English version of this article. We especially thank the anonymous reviewers and the editors Geoffrey Braswell and Maria Gutierrez, whose comments and suggestions improved the original version. The ideas expressed in this work are the responsibility of the authors.

Data Availability Statement. Bioanthropological collections analyzed in the present study are curated in the Museo de Antropología-FFyH, UNC (Córdoba, Córdoba), Museo
Arqueológico Provincial "Anibal Montes” (Río Segundo, Córdoba), and the Museo de la Región de Ansenuza "Anibal Montes" (Miramar, Córdoba).

Supplemental Material. For supplementary material accompanying this article, visit https://doi.org/10.1017/laq.2019.69.

Supplemental Table 1. Bioarchaeological and Isotopic Data.

Supplemental Table 2. Isotopic Data of Animals and Plants Potentially Consumed by the Populations of the Eastern Lowlands and Central Mountains Regions.

Supplemental Text 1. Protocol for the Stable Isotope Analysis of Collagen and Radiocarbon Dating.

\section{References Cited}

Ambrose, Stanley H.

1990 Preparation and Characterization of Bone and Tooth Collagen for Isotopic Analysis. Journal of Archaeological Science 17:431-451.

1993 Isotopic Analysis of Paleodiets: Methodological and Interpretative Considerations. In Investigations of Ancient Human Tissue, edited by Mary Sanford, pp. 59-130. Gordon and Breach Science, New York.

2000 Controlled Diet and Climate Experiments on Nitrogen Isotope Ratios in Rats. In Biogeochemical Approaches to Paleodietary Analysis, edited by Stanley H. Ambrose and M. Anne Katzenberg, pp. 243-259. Kluwer Academic, New York.

Ambrose, Stanley. H., and Lynette Norr

1993 Experimental Evidence for the Relationship of the Carbon Isotope Ratios of Whole Diet and Dietary Protein to those of Bone Collagen and Carbonate. In Prehistoric Human Bone: Archaeology at the Molecular Level, edited by Joseph Lambert and Gisela Grupe, pp. 1-37. Springer Verlag, Berlin.

Barberena, Ramiro, Francisco Zangrando, Adolfo Gil, Gustavo Martínez, Gustavo Politis, Luis Alberto Borrero, and Gustavo Neme

2009 Guanaco (Lama guanicoe) Isotopic Ecology in Southern South America: Spatial and Temporal Tendencies, and Archaeological Implications. Journal of Archaeological Science 36:2666-2675.

Barrientos, Gustavo

1999 Metodología de análisis de hipoplasia del esmalte dental aplicada al estudio de poblaciones prehispánicas del sudeste de la Región Pampeana. Revista Argentina de Antropología Biológica 2:307-322.

Bernal, Valeria, Paula Novellino, Paula González, and Sergio Iván Pérez

2007 Role of Wild Plant Foods among Late Holocene Hunter-Gatherers from Central and North Patagonia (South America): An Approach from Dental Evidence. American Journal of Physical Anthropology 133:1047-1059.

Bonofiglio, Marta

2010 Fuentes y ollas: Cocinas y cocineros en la Loma Alta. Memorias del pueblo Revista del Museo Histórico Municipal "La Para” 10(9-10):25-40.

Bonomo, Mariano, Clara Scabuzzo, Gustavo Politis, and Alejandro Zucol

2017 Stable Carbon and Nitrogen Isotope Studies in the Parana River Delta (Argentina): An Approach 
to Prehispanic Diets. Latin American Antiquity 28:105126.

Buikstra, Jane, and Douglas Ubelaker

1994 Standards for Data Collection from Human Skeletal Remains. Arkansas Archaeological Survey Research Series No. 44. Fayetteville, Arkansas.

Cabido, Marcelo, Sebastian Zeballos, Marcelo Zak, María L. Carranza, Melisa Giorgis, Juan J. Cantero, and Alicia T. R. Acosta

2018 Native Woody Vegetation in Central Argentina: Classification of Chaco and Espinal Forests. Applied Vegetation Science 21(2):1-14.

Castro Olañeta, Isabel

2002 Recuperar las continuidades y transformaciones: Las juntas y borracheras de los indios de Quilino y su participación en la justicia colonial. In Los pueblos de indios del Tucumán colonial: Pervivencia y desestructuración, edited by Judith Farberman and Raquel Gil Montero, pp. 175-202. UNQ Ediciones-Ediunju, Jujuy, Argentina.

2006 Transformaciones y continuidades de las sociedades indígenas en el sistema colonial: El pueblo de indios de Quilino a principios del siglo XVII. Alción Editora, Córdoba, Argentina.

Colobig, María de los Milagros, Jorge Sánchez, and Alejandro Zucol

2015 Análisis de macrorrestos vegetales en el sitio arqueológico Los Tres Cerros 1 (isla Las Moras, Victoria, Entre Ríos). Revista del Museo de Antropología 8(1):115124.

Coltrain, John, and Steven Leavitt

2002 Climate and Diet in Frea Mont Prehistory: Economic Variability and Abandonment of Maize Agriculture in the Great Salt Lake Basin. American Antiquity 67:453-485.

Cornero, Silvia, Paula del Rio, and Carlos Cerutti

2013 Sitios con "Hornitos" del Holoceno tardío en el Chaco Austral: Colonia Dolores, Dpto. San Justo, Pcia. de Santa Fe. Anuario de Arqueología 5:103-115.

Cuccina, Andrea, and Vera Tiesler

2003 Dental Caries and Antemortem Tooth Loss in the Northern Petén Area, Mexico: A Biocultural Perspective on Social Status Differences among the Classic Maya. American Journal of Physical Anthropology 122:1-10.

DeNiro, Michael J., and Samuel Epstein

1981 Influence of Diet on the Distribution of Nitrogen Isotopes in Animals. Geochimica et Cosmochimica Acta 45:341-351.

Ehleringer, James R., Thure E. Cerling, and Brent R. Helliker $1997 \mathrm{C}_{4}$ Photosynthesis, Atmospheric $\mathrm{CO}_{2}$, and Climate. Oecologia 112:285-299.

Fabra, Mariana

1999 Rescatando el patrimonio arqueológico de la provincia de Córdoba: La arqueología de rescate como medio para revalorizar el pasado. Manuscript on file, Secretaría de Extensión Universitaria, Universidad Nacional de Córdoba, Argentina.

Fabra, Mariana, and Claudina González

2015 Diet and Oral Health of Populations that Inhabited Central Argentina (Córdoba Province) during Late Holocene. International Journal of Osteoarchaeology 25:160-175.

Fabra, Mariana, Claudina González, and Silvana Robin

2015 Evidencias de violencia interpersonal en poblaciones del piedemonte y las llanuras de Córdoba (Argentina) a finales del Holoceno tardío. Runa 36(1):5-27.
Fabra, Mariana, Claudina González, and Soledad Salega

2012 Modos de vida e historia biológica de poblaciones de las Sierra y Llanuras de Córdoba (Argentina): Aproximaciones desde el registro bioarqueológico. Revista Argentina de Antropología Biológica 14:87104

Fabra, Mariana, Rodrigo Nores, Soledad Salega, and Claudina González

2014 Entre las sierras y el Mar: Investigaciones bioarqueológicas en el noroeste de la región pampeana (costa sur Laguna Mar Chiquita, Córdoba, Argentina). In Avances recientes en la Bioarqueología Sudamericana, edited by Leandro Luna, Claudia Aranda, and Jorge Suby, pp. 205-231. Grupo de Investigaciones en Bioarqueología, Ciudad Autónoma de Buenos Aires.

Fabra, Mariana, Soledad Salega, Claudina González, Risha Smeding, and Eduardo Pautassi

2008 Arqueología de rescate en la costa sur de la Laguna Mar Chiquita: Sitio arqueológico El Diquecito. Memorias del Pueblo: Revista del Museo Histórico Municipal La Para 8(8):37-46.

Flensborg, Gustavo, Gustavo Martínez, and Augusto Tessone

2018 First Approach to the Paleodiet of Hunter-Gatherers through Stable Isotopes $\left(\delta^{13} \mathrm{C}\right.$ and $\left.\delta^{15} \mathrm{~N}\right)$ in the Eastern Pampa-Patagonia Transition during the Middle Holocene. Journal of Archaeological Science: Reports 17:571-580.

Giardina, Miguel, Mercedes Corbat, Clara Otaola, Laura Salgán, Andrew Ugan, Gustavo Neme, and Adolfo Gil

2014 Recursos y dietas humanas en Laguna Llancanelo (Mendoza; Nordpatagonia): Una discusión isotópica del registro arqueológico. Magallania 42(1):111-131.

Gil, Adolfo

2003 Zea mays on the South American Periphery: Chronology and Dietary Importance. Current Anthropology 44:295-300.

Gil, Adolfo, Lumila Menéndez, Juan Pablo Atencio, Eva Peralta, Gustavo Neme, and Andrew Ugan

2017 Estrategias humanas, estabilidad y cambio en la frontera Agrícola sur Americana. Latin American Antiquity 29:6-26.

Gil, Adolfo, Gustavo Neme, Robert Tykoy, Paula Novellino, Valeria Cortegoso, and Victor Duran

2009 Stable Isotopes and Maize Consumption in Central Western Argentina. International Journal of Osteoarchaeology 19:215-236.

Gil, Adolfo, Robert Tykot, Neme Gustavo, and Nicole Shelnut

2006 Maize on the Frontier: Isotopic and Macrobotanical Data from Central-Western Argentina. In Histories of Maize: Multidisciplinary Approaches to the Prehistory, Biogeography, Domestication, and Evolution of Maize, edited by John Staller, Robert Tykot, and Bruce Benz, pp. 199-214. Academic Press, New York.

González, Claudina

2016 Dieta y salud oral en poblaciones del centro de Argentina durante el Holoceno tardío. PhD dissertation, Facultad de Filosofía y Humanidades, Universidad Nacional de Córdoba, Argentina.

González, Claudina, and Mariana Fabra

2011 Estimaciones acerca de la salud de poblaciones que ocuparon la región austral de las sierras pampeanas en el holoceno tardío: Una aproximación desde la Antropología Dental. Revista del Museo de Antropología 4:161-178.

González, Claudina, and Mariana Fabra

2018 Desgaste dental y hábitos dietarios en poblaciones 
arqueológicas del Centro de Argentina. Revista Arqueología 24(2):133-159.

Guaciara, Santos, John Southon, Kevin Druffel-Rodriguez, Sheila Griffin, and Maya Mazon

2004 Magnesium Perchlorate as an Alternative Water Trap in AMS Graphite Sample Preparation: A Report on Sample Preparation at the KCCAMS Facility at the University of California, Irving. Radiocarbon 46:165173.

Hillson, Simon

2001 Recording Dental Caries in Archaeological Human Remains. International Journal of Osteoarchaeology 11:249-289.

Huss-Ashmore, Rebecca, Alan Goodman, and George Armelagos

1982 Nutritional Inference from Paleopathology. In Advances in Archaeological Method and Theory, edited by Michael B. Schiffer, pp. 395-474. Academic Press, New York.

Lukacs John

1989 Dental Paleopathology: Method for Reconstructing Dietary Patterns. In Reconstruction of Life from the Skeleton, edited by Mehmet Yasar Iscan and Kenneth Kennedy, pp. 261-286. Wiley-Liss, New York. Laguens, Andrés

1999 Arqueología del contacto hispano-indígena: Un estudio de cambios y continuidades en las Sierras Centrales de Argentina. BAR International Series 801. British Archaeological Reports, Oxford.

Laguens, Andrés, and Mirta Bonnin

2009 Sociedades indígenas de las Sierras Centrales: Arqueología de Córdoba y San Luis. Universidad Nacional de Córdoba, Córdoba, Argentina.

Laguens, Andrés, Mariana Fabra, Guaciara Macedo dos Santos, and Darío Demarchi

2009 Paleodietary Inferences Based on Isotopic Data for Pre-Hispanic Populations of the Central Mountains of Argentina. International Journal of Osteoarchaeology 19:237-249.

Lanfranco, Luis Pezo, and Sabine Eggers

2010 The Usefulness of Caries Frequency, Depth, and Location in Determining Cariogenicity and Past Subsistence: A Test on Early and Later Agriculturalists from the Peruvian Coast. American Journal of Physical Anthropology 143:75-91.

L'Heureax, Gabriela Lorena

2000 Estudio comparativo de indicadores de adecuación fisiológica y salud bucal en muestras de restos humanos del sudeste de la región pampeana. Relaciones de la Sociedad Argentina de Antropología 25:51-73.

Longin, Robert

1971 New Method of Collagen Extraction for Radiocarbon Dating. Nature 230:241-242.

Lopez, Maria Laura

2015 Prácticas culinarias como medio para la reproducción social de los grupos prehispánicos de las sierras de Córdoba. In Condiciones de posibilidad de la reproducción social en sociedades prehispánicas y coloniales tempranas en las Sierras Pampeanas (República Argentina), edited by Julian Salazar, pp. 117-212. Centro de Estudios Históricos Prof. Carlos S.A. Segreti, Córdoba, Argentina.

López, María Laura, Matías Medina, and Diego Rivero

2015 First Records of Chenopodium spp./Amaranthus spp. Starch Grains and their Relevance to the Study of the Late Holocene Human Subsistence in Central Argentina. Holocene 25:288-295.

Loponte, Daniel, and Alejandro Acosta

2007 Horticultores amazónicos en el Humedal del Paraná Inferior: Los primeros datos isotópicos de la dieta. In Arqueología en las pampas, edited by Cristina Bayón, Alejandra Pupio, María I. González, Nora Flegenheimer, and Magdalena Frère, pp. 75-93. Sociedad Argentina de Antropología, Buenos Aires.

Luti, Ricardo, María Bertrán de Solis, Francisca M. Galera, Nelida Muller de Ferreira, Mercedes Berzal, Manuel Nores, Miguel Ángel Herrera, and Juan Carlos Barrera

1979 Vegetación. In Geografía Física de la Provincia de Córdoba, edited by Juan Vázquez, Roberto Miatello, and Marcelo Roqué, pp. 45-138. Editorial Boldt, Buenos Aires.

Martínez, Gustavo, Francisco Zangrando, and Luciano Prates 2009 Isotopic Ecology and Human Paleodiets in the Lower Basin of the Colorado River, Buenos Aires Province, Argentina. International Journal of Osteoarchaeology 19:281-296.

Medina, Matías, Silvia Grill, and María Laura López

2008 Palinología arqueológica: Su implicancia en el estudio del prehispánico tardío de las sierras de Córdoba (Argentina). Intersecciones en Antropología 9:99-112.

Medina, Matías, María Laura López, and Eduardo Berberian 2009 Agricultura y recolección en el tardío prehispánico de las Sierras de Córdoba (Argentina): El registro arqueobotánico de C. Pun.39. Arqueología 15:217-229.

Medina, Matías, Sebastián Pastor, and Eduardo Berberian

2014 "Es gente fácil de moverse de una parte a otra": Diversidad en las estrategias de subsistencia y movilidad prehispánicas tardías (Sierras de Córdoba, Argentina). Complutum 25(1):73-88.

Métraux, Alfred

1996 Etnografía del Chaco. Editorial El Lector, Paraguay.

Molnar, Susan

1971 Human Tooth Wear, Tooth Function and Cultural Variability. American Journal of Physical Anthropology 34:175-190.

Novellino, Paula

2002 Bioarqueología en el sur de Mendoza. In Entre montañas y desiertos: Arqueología del sur de Mendoza, edited by Adolfo Gil and Gustavo Neme, pp. 119-140. Sociedad Argentina de Antropología, Buenos Aires.

Novellino, Paula, and Adolfo Gil

2007 Estrés nutricional, hipoplasia y explotación de recursos en el Centro-Sur de Mendoza (Argentina). Intersecciones en Antropología 8:15-26.

Novellino, Paula, Adolfo Gil, Gustavo Neme, and Víctor Durán

2004 El consumo de maíz en el Holoceno tardío del oeste argentino: Isótopos estables y caries. Revista Española de Antropología Americana 34:85-110.

Osterrieth, Margarita, and Alejandro Zucol

2000 Paleoenvironmental Reconstruction in Late Quaternary Paleosoils of the Pampean Plains (Argentina). In Proceedings of the 3 rd International Meeting of Phytolithic Research: Abstracts, pp. 15-16. Brussels, Belgium.

Ottalagano, Flavia, and Daniel Loponte

2016 Stable Isotopes and Diet in Complex Hunter 
Gatherers of Paraná River Basin, South America. Archaeological and Anthropological Sciences 9:865-877.

Pastor, Sebastián

2007 Arqueología del Valle de Salsacate y pampas de altura adyacentes (Sierras Centrales de Argentina). Una aproximación a los procesos sociales del período prehispánico tardío (900-1573 d.C.). PhD dissertation, Facultad de Ciencias Naturales y Museo, Universidad Nacional de La Plata, Argentina.

Pastor, Sebastián, María Laura López, and Diego Rivero

2012 Access to Maize (Zea mays) and Its Manipulation in Hunter-Gatherer Contexts in Central Argentina (c 30002500 Bp). Before Farming 4:1-10.

Pastor, Sebastián, Matias Medina, and Eduardo Berberian

2013 Poblados, casas y maizales. Arqueología del espacio residencial y productivo en las Sierras Centrales de Argentina (ca. 1100-300 AP). Revista Española de Antropología Americana 43(1):31-55.

Pastor, Sebastián, Andrea Recalde, Luis Tissera, Mariana Ocampo, Gabriela Truyol, and Stefanía Chiavassa-Arias

2015 Chamanes, Guerreros, Felinos: Iconografía de Transmutación en el Noroeste de Córdoba (Argentina). Boletín SIARB 29:71-85.

Pate, Donald

1994 Bone Chemistry and Paleodiet. Journal of Archaeological Method and Theory 1:161-209.

Piana de Cuestas, Josefina

1992 Los indígenas de Córdoba bajo el régimen colonial (1570-1620). Dirección General de Publicaciones de la Universidad Nacional de Córdoba, Córdoba, Argentina.

Piovano, Luis Eduardo, Daniel Ariztegui, Francisco Córdoba, Marcela Cioccale, and Florence Sylvestre

2009 Hydrological Variability in South America below the Tropic of Capricorn (Pampas and Patagonia, Argentina) during the Last $13.0 \mathrm{ka}$. In Past Climate Variability in South America and Surrounding Regions: Developments in Paleoenvironmental Research, edited by Francoise Vimeux, Florence Sylvestre, and Myriam Khodri, pp. 323-351. Springer, Berlin.

Rivero, Diego, and Matías Medina

2016 Human Colonization, Diet Breadth and Niche Construction during Sierras of Córdoba Holocene (Argentina). In Darwin's Legacy: The State of Evolutionary Archaeology in Argentina, edited by Hernan Muscio and Marcelo Cardillo, pp. 67-81. Archaeopress, Oxford.

Rivero, Diego, Matías Medina, Sebastián Pastor, and Andrea Recalde

2010 Variabilidad en la explotación de recursos faunísticos durante el Holoceno en las Sierras de Córdoba (Argentina): Una aproximación zooarqueológica. In Zooarqueología a principios del siglo XXI: Aportes teóricos, metodológicos y casos de estudio, edited by María Gutiérrez, Mariana De Nigris, Pablo Fernández, Miguel Giardina, Adolfo Gil, Andres Izeta, Gustavo Neme, and Hugo Yacobaccio, pp. 321-333. Ediciones del Espinillo, Buenos Aires.

Schoeninger, Margaret. J., and Michael J. DeNiro

1984 Nitrogen and Carbon Isotopic Composition of Bone
Collagen from Marine and Terrestrial Animals. Geochimica et Cosmochimica Acta 48:625-639.

Scott, Eugene Carol

1979 Dental Wear Scoring Technique. American Journal of Physical Anthropology 51:213-218.

Scott, Richard, and Christy G. Turner II

1988 Dental Anthropology. Annual Review Anthropology 17:99-126.

Simón-Soro, Aurea, and Alex Mira

2015 Solving the Etiology of Dental Caries. Trends in Microbiology 23(2):76-82.

Smith, B. Holly

1984 Patterns of Molar Wear in Hunter-Gatherers and Agriculturalists. American Journal of Physical Anthropology 63:39-56.

Sotelo de Narváez, Pedro

1583 Relación de las Provincias de Tucumán que dió P Sotelo de Narváez, vecino de aquellas provincias, al muy ilustre Sr. Lic. Cepeda. Relaciones Geográficas de Indias, España, Ministerio de Fomento, Madrid.

Tavarone, Aldana, María de los Milagros Colobig, and Mariana Fabra

2019 Late Holocene Plant Use in Lowland Central Argentina: Microfossil Evidence from Dental Calculus. Journal of Archaeological Science: Reports 26:1-12.

Tessone, Augusto, Francisco Zangrando, Gustavo Barrientos, Rafael Goñi, Hector Panarello, and Mariana Cagnoni

2009 Stable Isotope Studies in the Salitroso Lake Basin (Southern Patagonia, Argentina): Assessing Diet of Late Holocene Hunter-Gatherers. International Journal of Osteoarchaeology 19:297-308.

Brown Thomas A., D. Erle Nelson, John S. Vogel, and John R. Southon

1988 Improved Collagen Extraction by the Modified Longin Method. Radiocarbon 30:171-177.

Tieszen, Larry, and Tim Fagre

1993 Effect of Diet Quality and Composition on the Isotopic Composition of Respirated $\mathrm{CO}_{2}$, Bone Collagen, Bioapatite and Soft Tissues. In Prehistoric Human Bone: Archaeology at the Molecular Level, edited by Joseph Lambert and Gisele Grupe, pp. 121-155. Springer Verlag, Berlin.

Turner, Christy

1979 Dental Anthropological Indications of Agriculture among the Jomon People of Central Japan. American Journal of Physical Anthropology 51:619-636.

Yoneda, Minoru, Atsushi Tanaka, Yasuyuki Shibata, Masatoshi Morita, Kazuhiro Uzawa, Masashi Hirota, and Masa Uchida

2002 Radiocarbon Marine Reservoir Effect in Human Remains from the Kitakogane Site, Hokkaido, Japan. Journal of Archaeological Science 29:529-536.

Submitted July 24, 2018; Revised March 6, 2019; Accepted April 8, 2019 